\title{
CHARACTERIZATION OF A GLASS-BONDED CERAMIC WASTE FORM LOADED WITH U AND PU
}

by

W. Sinkler, T. P. O'Holleran, S. M. Frank,

M. K. Richmann, S. G. Johnson

Engineering Division

Argonne National Laboratory-West

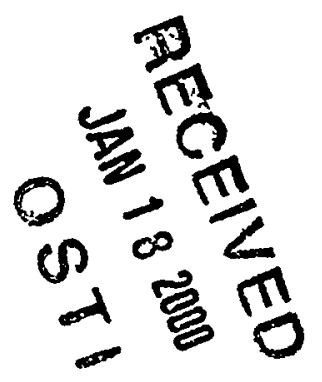

P. O. Box 2528

Idaho Falls, ID 8343-2528

\begin{abstract}
The submitted manuscript has been created by the University of Chicago as Operator of Argonne National Laboratory ("Argonne") under contract No. W-31-109-ENG-38 with the U. S. Deparment of Energy. The U.S. Government retains for itself, and others acting on its behalf, a paid-up nonexclusive, irrevocable worldwide license in said article to reproduce, prepare derivative works, distribute copies to the public, and perform publicly and display publicly, by or on behalf of the Government.
\end{abstract}

Materials Research Society

Scientific Basis for Waste Management XXIII

Boston, MA

November 29-December 3, 1999

*Work supported by the U.S. Department of Energy, Materials/Chemistry, Materials Characterization, under Contract W-31-109-ENG-38. 


\section{DISCLAIMER}

This report was prepared as an account of work sponsored by an agency of the United States Government. Neither the United States Government nor any agency thereof, nor any of their employees, make any warranty, express or implied, or assumes any legal liability or responsibility for the accuracy, completeness, or usefuiness of any information, apparatus, product, or process disclosed, or represents that its use would not infringe privately owned rights. Reference herein to any specific commercial product, process, or service by trade name, trademark, manufacturer, or otherwise does not necessarily constitute or imply its endorsement, recommendation, or favoring by the United States Government or any agency thereof. The views and opinions of authors expressed herein do not necessarily state or reflect those of the United States Government or any agency thereof. 


\section{DISCLAIMER}

Portions of this document may be illegible in electronic image products. Images are produced from the best available original document. 


\title{
W. SINKLER, T. P. O'HOLLERAN, S. M. FRANK, M. K. RICHMANN* AND S. G. JOHNSON
}

Argonne National Laboratory - West, P. O. Box 2528, Idaho Falls, ID 83403

*Argonne National Laboratory - East, 9700 South Cass Ave., Argonne, IL 60439

\begin{abstract}
This paper presents microscopic characterization of four samples of a ceramic waste form (CWF) developed for disposal of actinide-containing electrorefiner salts. The four samples were prepared to investigate the influence of water content and the Pu:U ratio on CWF microstructure and performance. While the overall phase content is not strongly influenced by either variable, the presence of water in the initial zeolite has a detectable effect on CWF microstructure. It is found to influence the distribution of the major actinide host phase, a $(\mathrm{U}, \mathrm{Pu}) \mathrm{O}_{2}$ mixed oxide.
\end{abstract}

\section{INTRODUCTION}

Argonne National Laboratory (ANL) has developed a spent fuel treatment process for sodiumbonded metallic spent nuclear fuel from the EBR II fast breeder reactor. The process involves electrometallurgical separation of the spent fuel in a $\mathrm{KCl}-\mathrm{LiCl}$ molten salt bath. The three products are a) cladding hulls remaining at the anode, along with elements noble to the electrorefinement, b) uranium metal which is deposited on the cathode, and c) the electrorefiner salt bath, in which $\mathrm{Na}, \mathrm{Pu}, \mathrm{U}$, rare earth, alkali and alkaline earth fission products accumulate.

Disposal of the electrorefiner salt is the most challenging aspect of the electrometallurgical spent fuel treatment. In order to immobilize the water soluble chlorides, the initial step in disposing of the salt is blending with zeolite $4 \mathrm{~A}$ in a v-mixer at $500^{\circ} \mathrm{C}$. This results in a reduction of the free chloride content to less than $1 \%$ of the initial quantity. Subsequently, the salt-blended zeolite is mixed with a borosilicate glass frit and hot isostatically pressed (HIP'ed). During HIP, the zeolite 4A transforms to sodalite, a mineral aluminosilicate phase which contains chlorine and alkali elements. The resulting material is a glass-ceramic in which the primary phases are glass and sodalite, with minor constituents nepheline $\left(\mathrm{NaAlSiO}_{4}\right)$, $(\mathrm{Pu}, \mathrm{U}) \mathrm{O}_{2}$ mixed oxide, halite $(\mathrm{NaCl})$ and a rare earth silicate containing some $\mathrm{Pu}$. The microstructure and leach behavior of this material has been presented in several previous papers [1-3].

Part of the qualification process for acceptance of the electrometallurgical treatment is to investigate the effect on the CWF of variations in processing and compositional parameters over ranges within which they may vary during operations. The present work addresses two important compositional parameters. The first of these is the water content. Water is introduced into the processing in slightly varying amounts due to the inevitable presence of a small quantity of water in the zeolite 4A. The second compositional variable addressed here is the ratio of $U$ to $\mathrm{Pu}$ in the electrorefiner salt. In the case of driver fuel processing, this ratio is typically large, on the order of 2:1. In the case of blanket fuel processing, which is planned at a later stage in the fuel treatment, the U:Pu ratio will be lower, on the order of 1:2.

The issue of water content is of particular interest for the CWF. The motivation for using zeolite for salt disposal is the well-known ability of zeolites to occlude salt ions [4]. While blending with zeolite dramatically reduces the overall free chloride quantity, previous studies of the CWF have suggested that occlusion may not occur in the case of the actinide salts. Instead, the $\mathrm{U}$ and $\mathrm{Pu}$ chlorides have been found to transform to a separate oxide phase during the salt/zeolite blending step. When water is present, the formation of $(\mathrm{U}, \mathrm{Pu}) \mathrm{O}_{2}$ is explainable as a direct reaction of actinide chlorides with water, which is strongly favored thermodynamically. However, the observed formation of a separate oxide phase rather than occlusion raises an important basic question as to whether zeolite occlusion of actinide salts can occur if the 
competing reaction with water is suppressed by using sufficiently dry zeolites, and/or artificially large actinide contents. The present study was in part designed to address this question.

\section{EXPERIMENTAL}

Four laboratory scale samples of CWF were produced as a test matrix shown in Table 1. At ANL-East, salts of composition given in Table 2 were blended with wet or dry zeolite $4 \mathrm{~A}$ for $20 \mathrm{~h}$ at $500^{\circ} \mathrm{C}$ under argon. The salt/zeolite blend had $10.5 \mathrm{wt} \%$ salt.

Table 1. Overview of experimental matrix showing sample designations

\begin{tabular}{|c|c|c|}
\hline zeolite $\mathrm{H}_{2} \mathrm{O}(\mathrm{w} \%)$ & U:Pu Ratio 3:1 & U:Pu Ratio 1:3 \\
\hline 0.12 & 1 & 2 \\
\hline 3.5 & 3 & 4 \\
\hline
\end{tabular}

Table 2. Approximate composition of actinide bearing 300 driver electrorefiner salt ( $w \%)$

\begin{tabular}{|c|c|c|c|c|c|c|}
\hline $\mathrm{LiCl}-\mathrm{KCl}^{\dagger}$ & $\mathrm{NaCl}$ & $\mathrm{CsCl}$ & $\mathrm{BaCl}_{2}$ & $\mathrm{RECl}_{3}$ & $\mathrm{AcCl}_{3}$ & others \\
\hline 65.0 & 12.7 & 2.1 & 1.0 & 7.9 & 10.1 & 1.2 \\
\hline
\end{tabular}

${ }^{\dagger}$ Eutectic compositon with $47.1 \mathrm{wt} \% \mathrm{KCl}$. RE: Rare earths; Ac: $\mathrm{Pu}$ and $\mathrm{U}$ in 3:1 or 1:3 ratio

Following blending, the salt-loaded zeolite was mixed with a borosilicate glass frit in 1:3 proportion by weight (glass:blended zeolite), and sealed in small 1" diameter evacuated HIP cans. At ANL-West, the samples were HIP'ed at $850^{\circ} \mathrm{C}$ for $1 \mathrm{~h}$ under $100 \mathrm{MPa}$ pressure. Powder $\mathrm{X}$-ray diffractometry (XRD), scanning and transmission electron microscopies (SEM and TEM) were performed on Scintag X1 ( $\mathrm{Cu} \mathrm{K \alpha}$ ), Zeiss DSM 960 and JEOL 2010 instruments, respectively. TEM sample preparation was performed using standard dimpling and ion milling techniques.

\section{RESULTS}

a) X-Ray Diffractometry

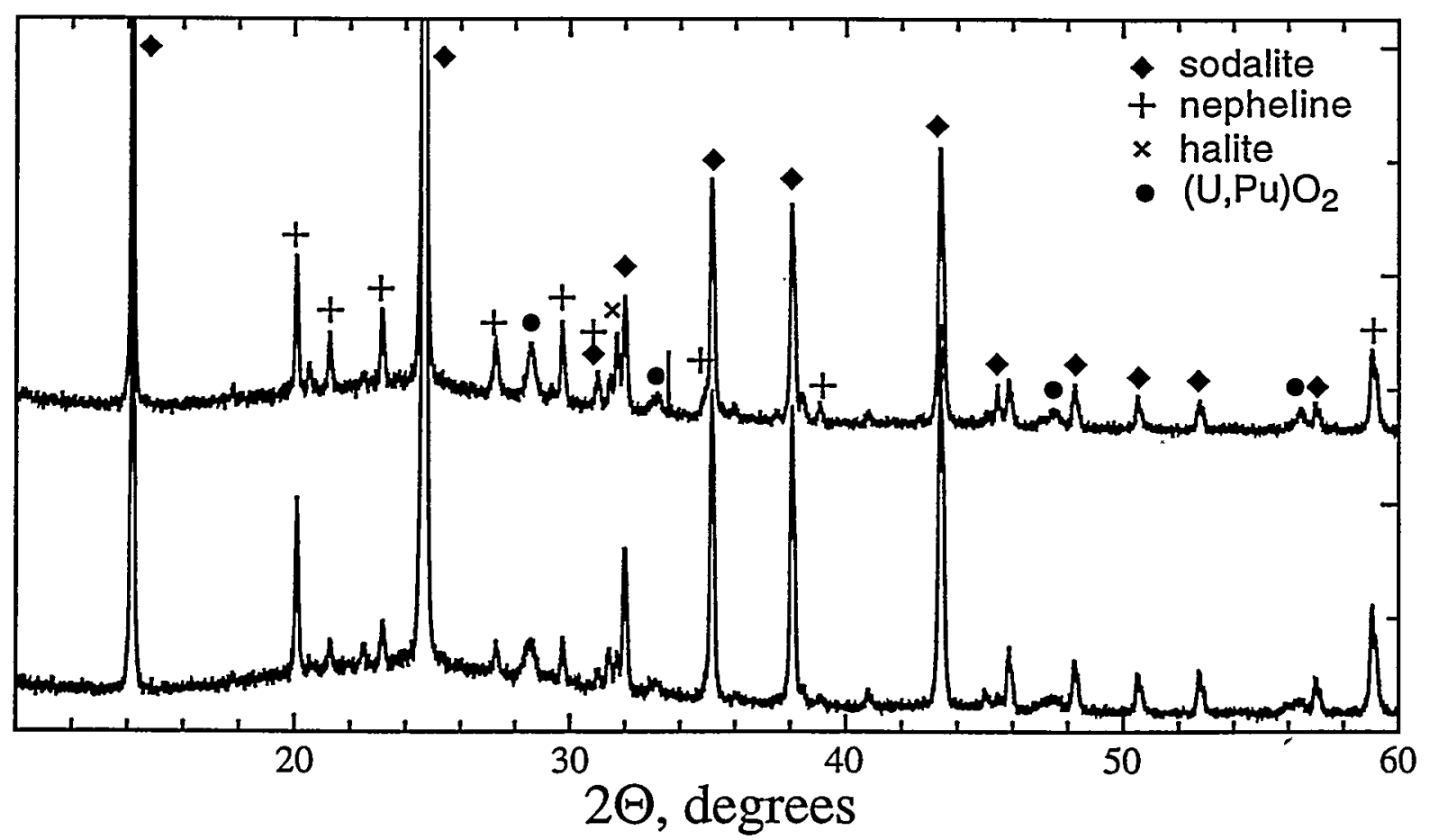

Fig. 1. XRD scans of samples 4 (top) and 2 (bottom). 
Fig. 1 shows XRD scans of samples 2 and 4. The phases identified in the scans are sodalite, nepheline, the mixed actinide oxide (U,Pu) $\mathrm{O}_{2}$ phase with fluorite structure, and halite. In addition, the broad rise in the background intensity near $25^{\circ} 2 \Theta$ is consistent with the presence of a glass phase. As can be seen, the traces are nearly identical, indicating that the influence of water on the phase content of the final CWF is minor. The only significant variation of phase content caused by the presence of water is an increase in the peaks associated with halite for high water content. For changing U:Pu ratio, the only discernable influence in the XRD trace was on the lattice parameter of the mixed oxide $(\mathrm{U}, \mathrm{Pu}) \mathrm{O}_{2}$ phase. This varied in a way consistent with solid solutions with $U: P u$ of $3: 1$ or $1: 3$.

\section{b) Scanning Electron Microscopy}

Fig. 2 shows the typical appearance of wet and dry zeolite in SEM, backscattered electron (BSE) mode. The predominant microstructure of the CWF consists of polycrystalline sodalite regions joined by a glass phase. The lightest features in the images are actinide and rare-earth bearing regions. Sodalite regions appear a more continuous light tone and glass regions appear diffuse and darker. In the case of sample 1 made with dry zeolite, the actinide species appear to be more homogeneously distributed within the sample, giving the BSE image a slightly noisy appearance. In contrast, actinide-rich regions in the BSE image of the sample made with wet zeolite are more strongly clustered. No significant difference was found in SEM between samples made with high and low U:Pu ratios.
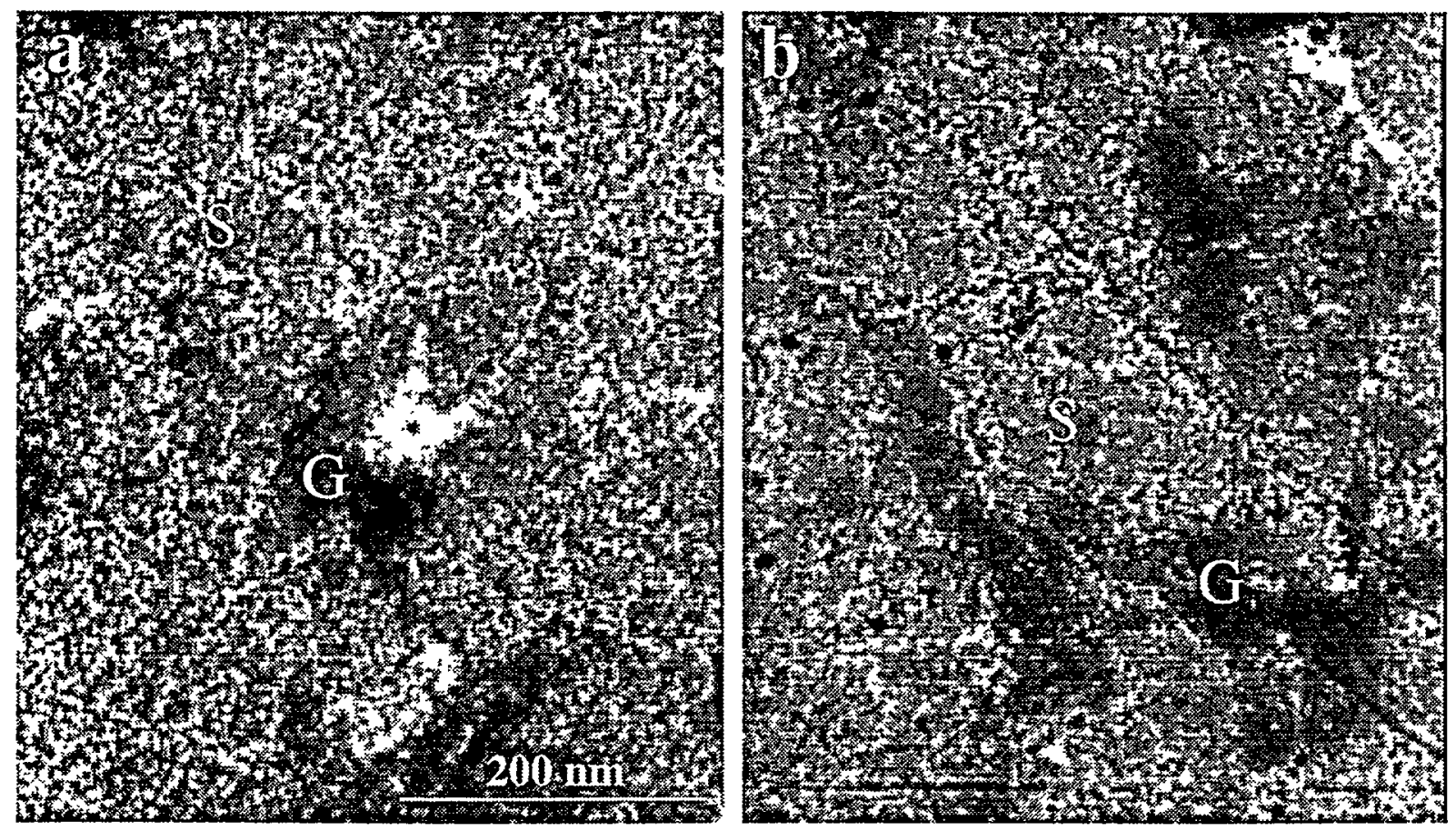

Fig. 2. SEM BSE micrographs of samples 1 (a) and 3 (b). G: Glass; S: Sodalite; bright particulate phase is actinide oxide.

\section{c) Transmission Electron Microscopy}

Fig. 3 shows a typical low-magnification microstructure image from sample 1. The major glass and sodalite phases, as well as halite and the mixed oxide phase, are all visible in the image. Energy dispersive spectroscopy (EDS) spectra from the glass and sodalite phases do not differ significantly from those presented previously [3]. In particular, the actinide content in these phases is negligible. The major actinide-bearing phase in the CWF is the mixed oxide. Both this phase as well as halite tend to be found within the glass near the glass/sodalite boundary, as shown in Fig. 3. 
Fig. 4 shows a cluster of mixed oxide crystals in sample 3 , which is identical to sample 1 except that it was made using wet zeolite. There is a clear difference between the distribution of mixed oxide particles in Figs. 3 and 4, which was consistent in all observations of these samples. Mixed oxide clusters in the samples made with wet zeolite tended to have well-defined boundaries with a roughly constant density of fine mixed oxide particles within these boundaries. In contrast to this, use of dry zeolite tended to result in large but rather incoherent and ill-defined agglomerations of the mixed oxide phase, such as that seen in Fig. 3. While a clear microstructural difference was detected between samples made with high and low water contents, no difference among the samples as a function of the U:Pu ratio was detected using TEM.

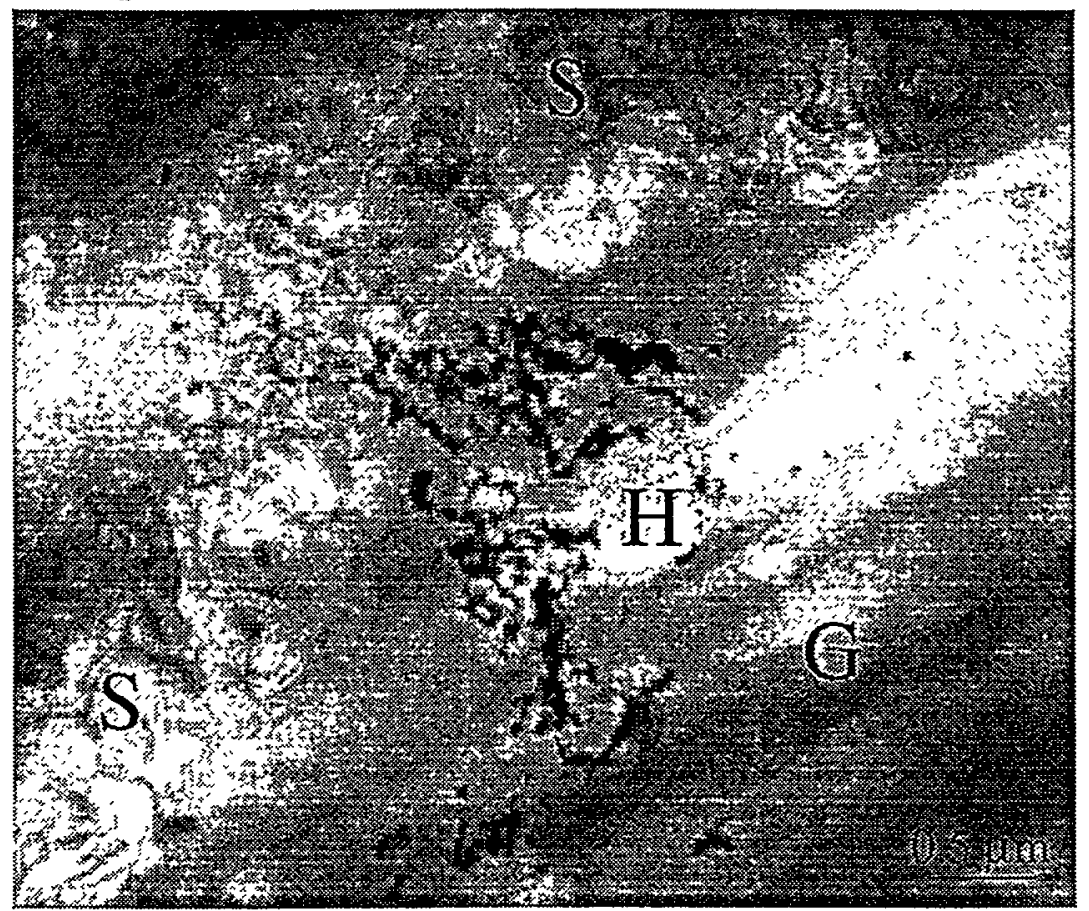

Fig. 3. Microstructure image of sample 1. S: Sodalite, G: Glass, H: Halite. The fine-grained dark phase is $(\mathrm{U}, \mathrm{Pu}) \mathrm{O}_{2}$, found in clusters of grains with approximately $20 \mathrm{~nm}$ crystallite size.

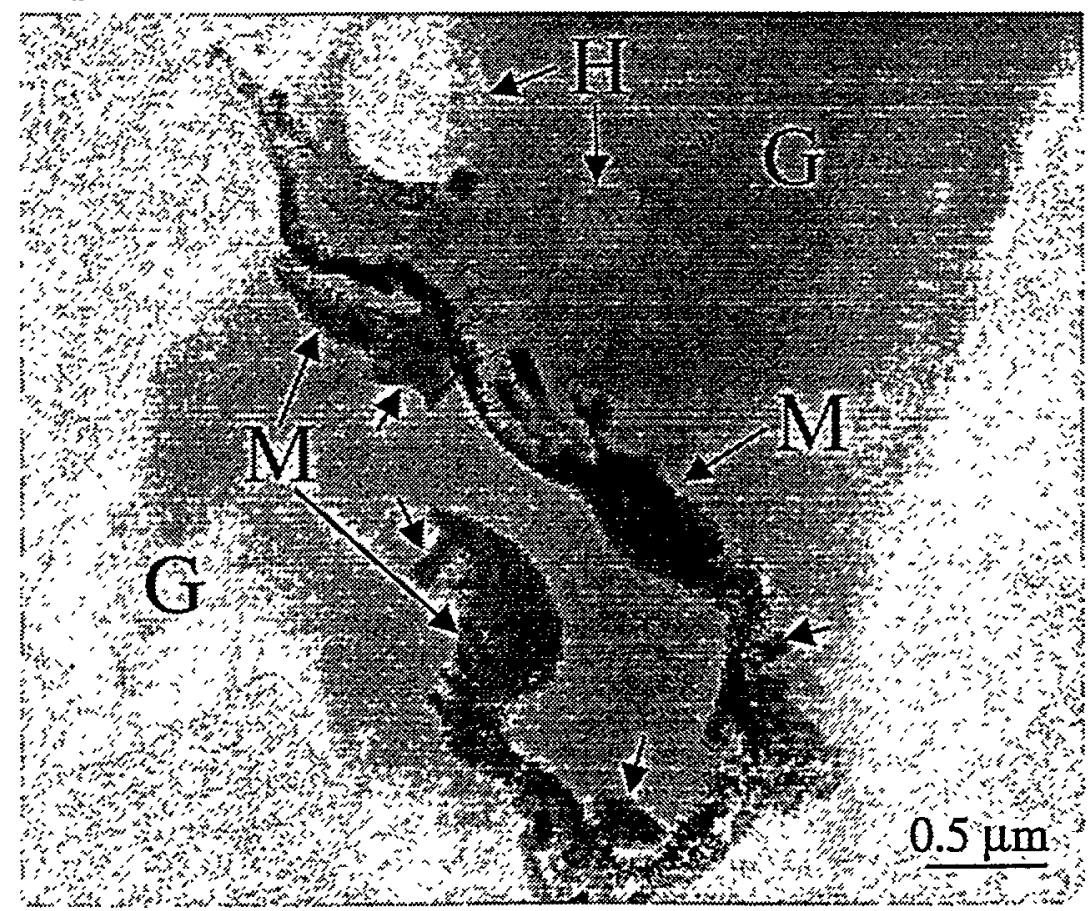

Fig. 4. Image from sample 3 showing an actinide-rich region in the glass phase. Short unlabeled arrows show examples of the rare earth based silicate phase. $M$ : mixed oxide clusters. 
In addition to the different morphology of clusters of mixed oxide particles, two other distinctions were noted between samples made with wet and dry zeolite. In samples made with dry zeolite, there were a significant number of larger single crystals of the mixed oxide phase, on the order of $100 \mathrm{~nm}$ up to sizes in excess of one micron. In contrast, such crystals were rare in the case of the samples made with wet zeolite. Finally, in a few instances, very fine mixed oxide crystals were found to have formed in the interior of sodalite grains or at sodalite grain boundaries in samples made with dry zeolite 4A. An example of this is shown as Fig. 5.

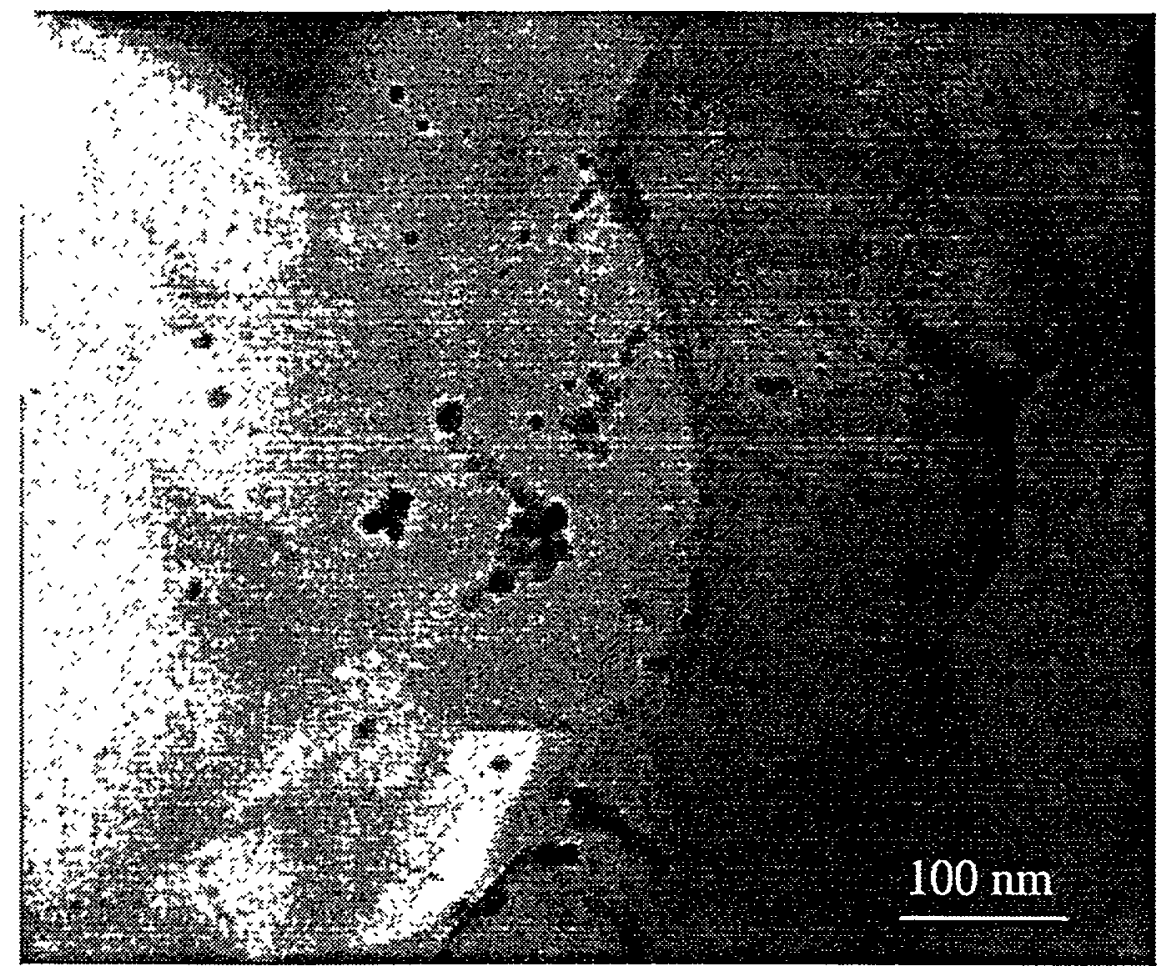

Fig. 5. TEM bright field image from sample 1 showing sodalite grains with intragranular precipitates of the mixed oxide phase (small dark inclusions).

While the majority of actinides were contained in the mixed oxide phase, a rare earth based silicate phase was found in all four samples. Examples of several rare earth based silicate crystals are seen in Fig. 4. This phase forms faceted crystals with somewhat larger sizes than the mixed oxide phase. They are commonly found within or at the boundaries of mixed oxide clusters (see Fig. 4). EDS spectra showed strong rare earth lines (primarily $\mathrm{Nd}$ and $\mathrm{Ce}$ ), as well as a minor actinide component. The ratio of $\mathrm{Pu}$ to $\mathrm{U}$ was consistently higher than in any nearby mixed oxide, judging from significantly stronger intensity of the $\mathrm{Pu} L \alpha$ characteristic $\mathrm{x}$-ray relative to $U L \alpha$. Because of the small quantity of this phase, its role as an actinide host is nevertheless small. The rare earth based silicate could not be indexed to any rare earth or actinide silicate phase found the JCPDS database. An orthorhombic unit cell was determined to which all diffraction patterns could be indexed. The cell parameters are:

$a=22.9 \AA ; b=9.9 \AA ; c=7.2 \AA$

The errors are approximately $2 \%$ on the relative axis lengths, and $5 \%$ on the absolute lengths (due to uncertainty in the microscope camera length). Evidence for $\mathrm{a} b$ glide plane parallel to a and an a glide plane parallel to $c$ was found in systematic absences. In addition, reflections with index 1 odd showed a pronounced streaking in the a-axis direction, indicating that there is significant stacking disorder along the a-axis. 


\section{DISCUSSION}

While the phase content of the glass bonded sodalite CWF is relatively independent of zeolite water content and U:Pu ratio within the present ranges, a microstructural effect of high water levels was detected by TEM and SEM. The present results suggest that the water content of the zeolite 4A may influence the kinetics of actinide oxide formation. In particular, the strong clustering of actinide oxide crystals seen in Fig. 4 suggest that this region originated from the decomposition of a particle of an initial chloride phase containing actinides and rare earths by reaction with water. The reaction with water occurs during salt/zeolite blending, since it is known that the much of the actinide oxide forms during this processing step. After formation of the actinide-bearing clusters, the mobility of actinides is greatly reduced. The observation of tightly constrained clusters with well defined morphology in the case of samples made with wet zeolite $4 \mathrm{~A}$ thus suggests that these clusters represent the outlines of initial chloride particles.

In the case of samples made with dry zeolite, the clusters of actinide-bearing crystals are less well defined. This is consistent with a more sluggish decomposition, occurring perhaps at higher temperature, thus allowing the salt particles to melt and disperse via diffusion prior to transformation to oxides and subsequent immobilization. More sluggish actinide oxide phase formation is also consistent with the observed greater quantity of large ( $>100 \mathrm{~nm}$ diameter) actinide oxide crystals in the samples made with dry zeolite $4 \mathrm{~A}$. The formation of larger crystals is aided by more controlled conditions of growth and a reduced thermodynamic driving force. In the case of a reaction not with water but with oxygen deriving from other phases in the CWF (the glass or zeolite), the thermodynamic driving force would be reduced. The common observation of halite crystals near to clusters of the mixed oxide phase (see Fig. 3) supports a transformation of the actinide chlorides to oxides by ion exchange with sodium.

Finally, the present work suggests that when the water content is insufficient for reacting all of the actinide chloride to oxide, competing mechanisms such as actinide salt occlusion into the zeolite 4A may become viable. Fig. 5 illustrates the presence of intragranular and intergranular actinide oxide precipitates, which are occasionally found in sodalite regions in samples made with dry zeolite 4A. This suggests that the zeolite from which the sodalite has formed initially absorbed actinides. Precipitation of the actinides intergranularly as oxides may then have occurred during the transformation of zeolite $4 \mathrm{~A}$ to sodalite.

\section{ACKNOWLEDGMENTS}

Argonne National Laboratory is operated for the U. S. Department of Energy by the University of Chicago. This work was supported by the Department of Energy, Nuclear Energy Research and Development Program, under contract No. W-31-109-ENG-38.

\section{REFERENCES}

1. S. M. Frank, K. Bateman, T. DiSanto, S. G. Johnson, T. Moschetti, M. Noy, and T. P. O'Holleran, in Phase Transformations and Systems Driven Far from Equilibrium, MRS Symp. Proc., Vol. 481, E. Ma, P. Bellon, M. Atzmon, and R. Trivedi, Editors. MRS, Pittsburgh. (1998).

2. T. L. Moschetti, T. P. O'Holleran, S. M. Frank, S. G. Johnson, D. W. Esh, and K. M. Goff, Ceramic Transactions 94, to be published, 1999.

3. W. Sinkler, D. W. Esh, T. P. O'Holleran, S. M. Frank, T. L. Moschetti, K. M. Goff, and S. G. Johnson, Ceramic Transactions 94, to be published, 1999.

4. D. W. Breck, Zeolite Molecular Sieves, Wiley, New York (1974), p. 529 ff. 